\title{
Fluctuations in Stock Market Prices: What went wrong, its Implications to Nigerian Economy?
}

\author{
Vincent O. R. \\ Department of Computer Science, \\ Federal University of Agriculture, P. M. B. 2240 \\ Abeokuta, Nigeria.
}

\begin{abstract}
The Nigerian stock market recently witnessed a continuous drop in the All-Share Index and volume of traded securities. The stock market indices have moved far relative to their previous year's levels and banks and markets suddenly become clearly unstable or strained to the point where it may collapse. In order to forestall future happenings, this work therefore defines a method of training that provides a forecast of stock growth over a period of 52 weeks. The earnings per share, price earnings ratio and the closing prices are calculated. It is resolved that fluctuations can be averted if past knowledge is well studied and made active.
\end{abstract}

\section{General Terms}

Electronic Payment, Information Systems, E-commerce, and Business Computing.

\section{Keywords}

Fluctuation, Economy, Stock Market, Economy Meltdown and Global financial crisis.

\section{INTRODUCTION}

Stock market is an organized and regulated market where securities (bonds, notes, shares) are bought and sold at prices governed by the forces of demand and supply. A stock market is a public entity for the trading of company stock and derivatives at an agreed price; these are securities listed on a stock exchange as well as those only traded privately. The stocks are listed and traded on stock exchanges which are entities of a corporation or mutual organization specialized in the business of bringing buyers and sellers of the organizations to a listing of stocks and securities together[1].Stock prices reflect all available information and the quicker they are in absorbing accurately new information, the more efficient is the stock market in allocating resources. Therefore, vast amount of capital is traded through the stock market all around the world.National economies are strongly linked and heavily influenced by the performance of their stock markets[2, 3]. Recently, the markets have become a more accessible investment tool, not only for strategic investors but for common people as well. Liberalizations and deregulations of markets for financial sector development to facilitate economic growth have also been encouraged by the drastic shift towards property-owning economies and the concomitant growing demand for access to capital [4].

In Nigerian, stock market witnessed a continuous drop in the All-Share Index and volume of traded securities. The banking sub-sector was affected by a credit contraction as most foreign

\author{
Bamiro K. \\ Department of Computer Science, \\ Federal University of Agriculture, P. M. B. 2240 \\ Abeokuta, Nigeria.
}

banks reduced their credit lines, exchange rate exposure, and the continuous decline in the NSE eroded their profitability. The decline in the revenue receipts by the three tiers of government, leading to a contraction in the fiscal sector. The contraction of the fiscal sector led to a crowding-out of the private sector credit, which in turn affected the real sector[5].Therefore, so many macro-economic maladjustments have unfolded in the Nigerian economy. Firstly, the naira exchange rate depreciated sharply and became more unstable than any other time in nearly a decade. The stock market indices have moved far relative to their previous year's levels and banks and markets suddenly become clearly unstable or strained to the point where it may collapse[6, 16]. Because of their exposure to foreign credit lines, the stock market by themselves and their loan customers were feared to be on the point of collapsing. Consequently, the Central Bank of Nigeria went to no end of limits to provide liquidity for the banks with a view to forestalling the feared consequences of the crisis.

The causes of the Global Financial Crisis 2008 on the Nigerian Capital Market can be summarized as liberalization of global financial regulation, Boom and Bust of the housing market, speculations, new financial architecture, poor credit rating, high risk loans and government policies[7]. The crisis led to the demise of large banking institutions, large size conglomerates and small businesses with governments, in even the wealthiest nations, providing rescue packages to bailout their financial systems.Based on the nature of the Nigerian economy, the financial crisis had an impact on theforeign exchange market. This was attributed to the disinvestment and repatriation ofcapital and dividends by foreign investors thereby intensifying the demand for foreigncurrencies. The implication for the Nigerian economy was borne by the various sectors of the economy such as; decline in oil revenues leading to revenue attrition for all tiers of government; reduced capital inflows into the economy; depletion of external reserves; demand pressure in the foreign exchange market; substantial decline in stock market capitalization and share prices[8].

Fluctuation is said to occur if there are a lot of shares for sale and no one is interested in buying them, the price will quickly fall. Fluctuations of stock prices and stock indices results into a problem of uncertainty which is common to all Stock Markets. The market uncertainties have to do with predicting the short and long-term future state of the stock price accurately. These features are undesirable for the investor but it is also unavoidable whenever the Stock Market is selected as the investment tool.Efficient Market Hypothesis (EMH) states that the current market price reflects the assimilation of all information available; therefore no prediction of the future 
changes in the price can be made giving past trading history information [9].

Fluctuations are caused by the economic factors of demand and supply that governs all financial market. Stock market fluctuations are when a company's stock prices changes in the market. On one hand, a company's stock has no direct effect on a company unless the company wants to raise more money by selling stock into the market. In that case, the current stock price determines how much money they will be able to raise where they sell shares into the market[10, 11 17]. Once the shares are sold into the market, however, the company is no longer affected directly by the share price. There are basically two (2) indirect effects of stock market fluctuations:

The first reason is that the company managers often own stock or options in the company. Since they want to do well personally, if the stock goes down, they will start to worry and work harder to make the company profitable and raise stock price. Sometimes, though, they just panic, cut and slash the look for ways to boost the stock price in the short-term at the expense of the company's long term health.

The second reason is the stock holders might be unhappy with a low stock price. That might put pressure on the board of directors of the company.

The aims of this study is to analysis the Nigerian stock market data and predict the short-term future of the stock market more specifically the prediction of the returns provided by the Stock Market on daily basis. This is to guide and advice prospective investors in deciding which shares to invest among the competing alternatives and indeed whether or not to invest in a particular stock. This study is to examine the feasibility of the prediction task in order to discover if the markets are fluctuating randomly or not.

\section{RELATED WORKS}

Some studies have presentedthe analysis of stock market prices, global economic meltdown and the application Neural Networks with various models. Among these are:Mahdi et al.designed a model to forecast stock price of steel industry, using artificial neural networks. They pointed that Investors have always been in the need of stock investment strategies that are going to create profit in a non-distant future, the stock market has an important characteristic: uncertainty. This uncertainty has to be eliminated (or at least minimized) to predict the near future and to make profit. The results from designed model show that if an artificial neural network is taught correctly, it can recognize the relationship between variables and it can help to forecast the stock price of steel industry with minimum error[12].

Shah discussed the Machine Learning techniques which have been applied for stock trading to predict the rise and fall of stock prices before the actual event of an increase or decrease in the stock price occurs. Such Applications are Support Vector Machines, Linear Regression, Prediction using Decision Stumps, Expert Weighting and Online Learning in detail along with the benefits and pitfalls of each method. He introduces the parameters and variables that can be used in order to recognize the patterns in stock prices which can be helpful in the future prediction of stocks and how Boosting can be combined with other learning algorithms to improve the accuracy of such prediction systems [9].
A study examined the impact of global financial crises on the Nigeria banking system. The risk of global economic crises was heightened; global aggregate demand has fallen while commodity prices collapsed. Because the global economy was inter-related, the Nigeria banking system was vulnerable. The study revealed that the financial crisis has caused depression of the Nigerian capital market and drop in the quality of part of the credit extended by banks for trading in the capital market, exchange rate risk tightening of liquidity, greater loan-loss provisioning, slower growth rate of banks' balance sheet in response to the crisis and higher provisioning leading to lower profitability among others. It was recommended that the federal government should implement the 7-point agenda, put up proactive measures to conserve the foreign reserves and timely injection of liquidity into the banking system[7].

Shorouq et al., proposed a model that identifies artificial neural network as an enabling tool for evaluating credit applications to support loan decisions in the Jordanian commercial banks. They used a multi-layer feed-forward neural network with back propagation learning algorithm to build up the proposed model and different representative cases of loan applications were considered based on the guidelines of different banks in Jordan, to validate the neural network model. However, their results indicate that artificial neural networks are a successful technology that can be used in loan application evaluation in the Jordanian commercial banks[13].

Nwude presented a work term 'the crash of the Nigerian stock market: what went wrong, the consequences and the panacea'.To achieve his aim, he did a mixture of archival and survey study was adopted. This necessitated pursuinginvestors (both institutional and private individual), regulators, and broking houses with questions to find out whatactually caused the problem. The result of the studies shows that Nigeria is experiencing a shortage of liquidity, flight of foreign funds, deteriorating capital market, depleting reserves and a depreciating currency. The public's perception over the financial crisis is that it was unforeseen and further aggravated by the global crisis. Result also indicated that Nigeria was indeed ready and capable of absorbing large foreign investments. The hype was also shared by banks and investors domestically. As a result of recapitalization, the banks were able to be more creative and offer more products to customers[1].

\section{STOCK PRICE ANALYSIS WITH NEURAL NETWORK}

A neural network may be considered as a data processing technique that maps, or relates, some type of input stream of information to an output stream of data. It has been proved that any function can be approximated to arbitrary accuracy by a neural network[14].An Artificial Neural Network (ANN) is an information processing paradigm that is inspired by the way biological nervous systems, such as the brain, process information.It is composed of a large number of highly interconnected processing elements (neurons) working in unison to solve specific problems. Neural networks like people learn by example. The neuron has two parts namely the synapse and the dendrites. The dendrites are extensions of a neuron which extends to other parts of a neuron to form a neural network.A biological neuron can be connected to other neurons as well as accepting connections from other neurons, which serves as the basis the network. Though those connections, electrical pulses are transmitted, and information is carried in the timing and the frequency with which these pulses are emitted. Learning in biological systems involves 
adjustments to the synaptic connections that exist between the neurons $[15,18]$.

This work employs artificial neural network in predicting the price of the stock market. Forward propagation algorithm is used as the training algorithm and the sigmoid function is employed as the activation function respectively. This network design will take in some stock market parameters as input, process it in the hidden layer and produce the forecast price alone. Also sigmoid transfer function will be used as the. The architecture of the Stock Prediction System is shown in figure 1. The work is divided into four steps: the input design, the process design, the output design and the storage design.

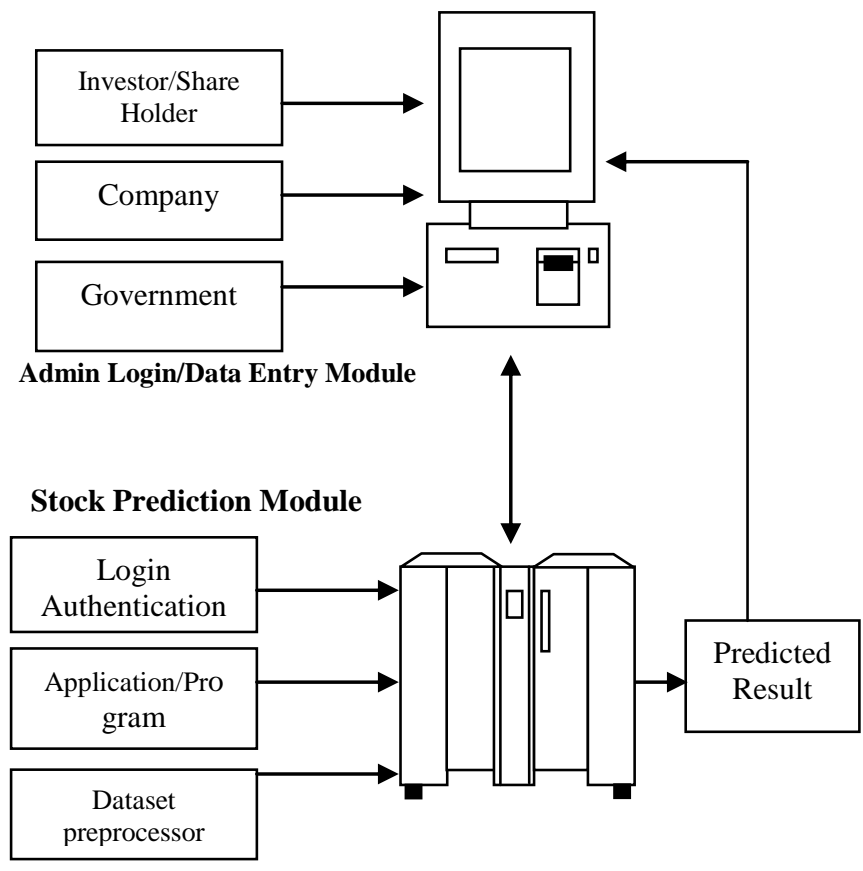

Figure 1: System Architecture for Stock Prediction Analysis

\subsection{Input Design}

Input refer to those things the system receives from its environment that are necessary to affect its operation. The system accepts the following categories of inputs database as

At the Stock prediction Module: The user supplies the numbers of week to predict its stock price and click on the Predict Stock button.The new system requires all essential data to be supplied by the user. The information is inputted through the keyboard and they are discharge on the video display unit as it is being supplied and later committed to the database. Data validation is ensured to avoid invalid input. The following are the attributes are used to analyses the data:

(i) Volume Traded: This refers to the number of shares that the market bought and sold on a given day. Changes in the network which is accompanied by changes in the volume of shares traded on the floor of the stock exchange.

(ii) Opening Price: This is the monetary worth of a particular share at the beginning of a market day. The market usually opens with the closing price of the previous market day. determined by the output required. The input data are the stock data for Sterling bank, First bank of Nigeria, Skye bank with a cross check of crude oil data. All data are extracted from Wikipedia. Table 1, 2, 3 show the yearly data Sterling, First and Skye banks from 2007 to 2011 .

Table 1: Stock Market Data from Data Bank Exchange Rate for Sterling Bank

\begin{tabular}{|l|l|l|l|}
\hline Years & $\begin{array}{l}\text { Volume } \\
\text { traded('000) }\end{array}$ & $\begin{array}{l}\text { Opening } \\
\text { Price(000 } \\
\text { units) }\end{array}$ & $\begin{array}{l}\text { Closing } \\
\text { Price(000 } \\
\text { units) }\end{array}$ \\
\hline 2007 & 40,000 & 3,500 & 3,700 \\
\hline 2008 & 48,000 & 1,700 & 2,000 \\
\hline 2009 & 36,000 & 2,000 & 3,000 \\
\hline 2010 & 57,600 & 4,500 & 3,800 \\
\hline 2011 & 61,200 & 5,000 & 5,500 \\
\hline
\end{tabular}

Table 2: Stock Market Data from Data Bank Exchange Rate for FBN

\begin{tabular}{|l|l|l|l|}
\hline & $\begin{array}{l}\text { Volume } \\
\text { Yraded('000) }\end{array}$ & $\begin{array}{l}\text { Opening } \\
\text { Price(1000 } \\
\text { units })\end{array}$ & $\begin{array}{l}\text { Closing } \\
\text { Price } \\
(1000 \\
\text { units })\end{array}$ \\
\hline 2007 & 55,500 & 5,000 & 5,700 \\
\hline 2008 & 60,000 & 7,500 & 7,800 \\
\hline 2009 & 80,000 & 8,000 & 8,000 \\
\hline 2010 & 85,000 & 8,500 & 9,500 \\
\hline 2011 & 100,000 & 10,000 & 12,500 \\
\hline
\end{tabular}

Table 3: Stock Market Data from Data Bank Exchange Rate for SKYE Bank

\begin{tabular}{|l|l|l|l|}
\hline Years & $\begin{array}{l}\text { volume } \\
\text { traded('000) }\end{array}$ & $\begin{array}{l}\text { Opening } \\
\text { Price(1000 } \\
\text { units) }\end{array}$ & $\begin{array}{l}\text { Closing } \\
\text { Price } \\
(1000 \\
\text { units) }\end{array}$ \\
\hline 2007 & 30,000 & 2,500 & 3,000 \\
\hline 2008 & 40,500 & 4,300 & 4,500 \\
\hline 2009 & 52,000 & 4,000 & 3,700 \\
\hline 2010 & 65,000 & 5,000 & 5,500 \\
\hline 2011 & 70,000 & 5,000 & 6,000 \\
\hline
\end{tabular}

(iii)Earnings per Share (EPS): This is an important ratio which demonstrates the relationship between the net earnings of a business. It represents the portion of a company's profit allocated to each outstanding share of common stock. EPS serves as an indicator of a company's profitability.

$E P S=$ Net profit after tax and preference dividend

Number of ordinary shares in issue

(iv) Earnings per share are generally considered to be the single most important variable in determining a share's price. It is also a major component of the price-to-earnings valuation ratio.

(v) Price Earnings Ratio (P/E Ratio): This is a valuation ratio which measures the relationship 
between the market value of a company's current share and its per-share earnings. It is also equal to the number of years earnings needed to cover the current market price.

$P / E$ Ratio $=\quad$ market value per share

(2)

Earnings per share

(iv) Closing price: This is achieved at the end of the trading for a particular market day. This value needs to be compared with the actual output of the neural network in order to obtain the error value for propagation.

(vi) Initial Weight: The connections between the nodes called neurons have to be assigned a random weight which will be multiplied with the input value of the neurons during the propagation process.

\subsection{Process Design}

The process stage involves converting the input parameters of a particular stock into a meaningful output. The neural network program for stock market prediction uses a supervised learning approach with forward Propagation. The network is forward propagated from the input layer through the two hidden layers to the output layer to yield an actual output.The processes involved are:

- Initialization of input data: The input attributes discussed above are entered into the network to commerce the training process.

- $\quad$ Each of the three stock market attributes are multiplied by their connection weight which are then summed to obtain the total weighted input to the other layer.

- The result is then passed through the sigmoid transfer function to calculates the activity

- Once the activities of all output units have been determined, the network computes the cumulative error.

Once the training process had been completed successfully, the network emerges with a pattern which is used in adjusting the weight of the connections. The adjusted weight is further analysed to predict the stock price for a particular period.

\subsection{Output Design}

The end product of any system is its outputs and is used to describe what emerge from computer system for the user to act upon. The main form used is the network running form in figure 2. The network running form performs the prediction task. The neural network running form receives the stock market attributes and forward propagates these set of attributes from the input layer through the hidden layer to the output layer using the updated weight obtained from the network training process to produce the forecast stock market price as the output of the running process shown in figure 3 .

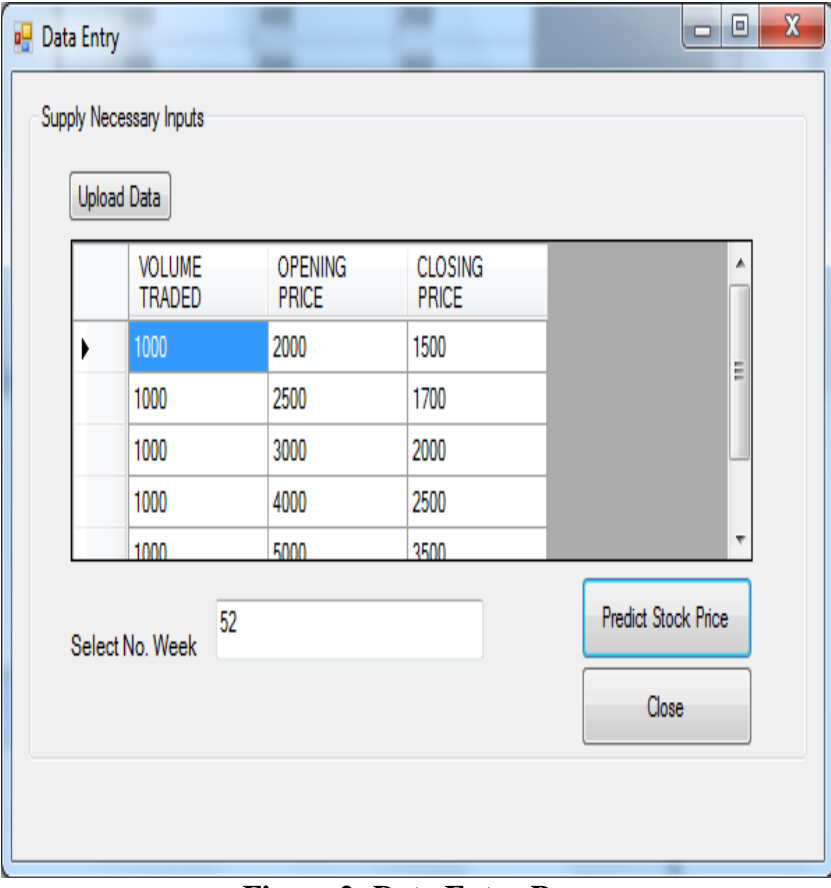

Figure 2: Data Entry Page

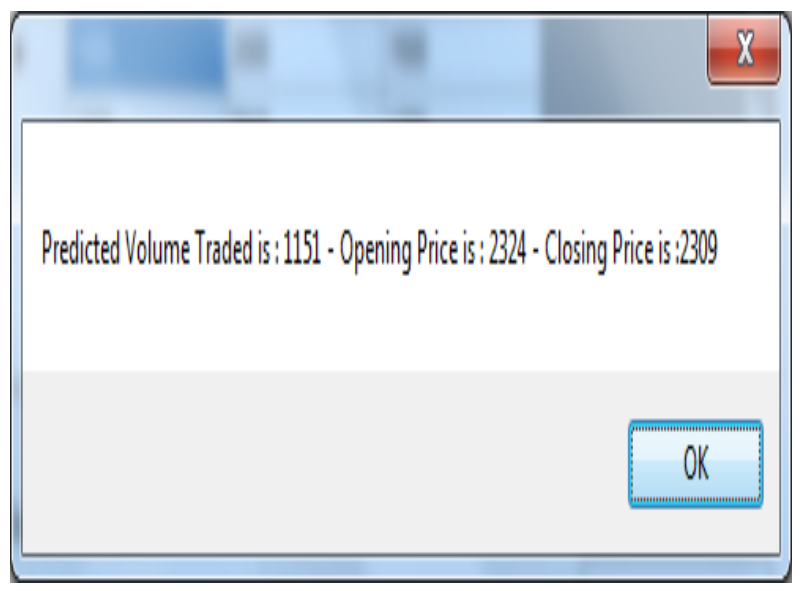

Figure 3 Forecasted Result Page

\subsection{Storage Design}

Data can be organized or stored using different methods: Network, Hierarchical, Distributed, Flat-file, object-oriented and Relational database. This work was designed using relational database model which consist of tables. It allows for collection of data items organized as a set of formallydescribed tables from which data can be accessed or reassembled in many different ways without having to reorganize the database tables. It also reduces the amount of redundant data in relations that can waste space and causes integrity problems. It also provides fast access to data from the relations. Table 4 shows that in 2011 stock market, Sterling bank have high net earnings. For each share sold, a profit of one hundred and fifty-two thousand, five hundred naira $(\mathrm{N} 152,500)$ was achieved.Tables 5 shows that in 2009 Stock market, First bank did not obtained any profit due to the Global economy meltdown that crippled the finances of most big banks. While SKYE bank experience a low net earnings. A loss of fifty naira for each share sold as seen from table 6 below.From the above tables, the P/E Ratios of the sampled data are calculated using (2): 
Table 4: Stock Market Data from Data Bank Exchange Rate for Sterling Bank

\begin{tabular}{|l|l|l|l|l|l|l|l|}
\hline YEARS & $\begin{array}{l}\text { Volume } \\
\text { traded('000) }\end{array}$ & $\begin{array}{l}\text { Opening } \\
\text { Price(1000 } \\
\text { units) }\end{array}$ & $\begin{array}{l}\text { Closing } \\
\text { Price (1000 } \\
\text { units) }\end{array}$ & $\begin{array}{l}\text { Net } \\
\text { Earnings(\#'000) }\end{array}$ & $\begin{array}{l}\text { Outstanding } \\
\text { Shares(1000 } \\
\text { units) }\end{array}$ & EPS(\#'000) & $\begin{array}{l}\text { P/E } \\
\text { RATIO(\#'000) }\end{array}$ \\
\hline 2007 & 40,000 & 3500 & 3700 & 7,980 & 100 & 79.8 & 46.4 \\
\hline 2008 & 48,000 & 1700 & 2000 & 14,250 & 500 & 28.5 & 70.2 \\
\hline 2009 & 36,000 & 2000 & 3000 & 35,500 & 500 & 71 & 42.3 \\
\hline 2010 & 57,600 & 4500 & 3800 & 55,900 & 1000 & 55.9 & 67.9 \\
\hline 2011 & 61,200 & 5000 & 5500 & 30,500 & 200 & 152.5 \\
\hline
\end{tabular}

Table 4 shows that in 2008 stock trading, Investors that traded with Sterling bank have high earnings growth of seventy thousand, two hundred naira per share deal.

Table 5: Stock Market Data from Data Bank Exchange Rate for FBN

\begin{tabular}{|l|l|l|l|l|l|l|l|}
\hline & $\begin{array}{l}\text { Volume } \\
\text { traded('000) }\end{array}$ & $\begin{array}{l}\text { Opening } \\
\text { Price(1000 } \\
\text { units) }\end{array}$ & $\begin{array}{l}\text { Closing } \\
\text { Price (1000 } \\
\text { units) }\end{array}$ & $\begin{array}{l}\text { Net } \\
\text { Earnings(\#'000) }\end{array}$ & $\begin{array}{l}\text { Outstanding } \\
\text { Shares(1000 } \\
\text { units) }\end{array}$ & EPS(\#'000) & $\begin{array}{l}\text { P/E } \\
\text { RATIO(\#'000) }\end{array}$ \\
\hline 2007 & 55,500 & 5,000 & 5,700 & 38,500 & 500 & 77 & 74 \\
\hline 2008 & 60,000 & 7,500 & 7,800 & 17,850 & 500 & 35.7 & 218.5 \\
\hline 2009 & 80,000 & 8,000 & 8,000 & 0 & 1,000 & 0 & 0 \\
\hline 2010 & 85,000 & 8,500 & 9,500 & 84,700 & 300 & 282.3 & 33.7 \\
\hline 2011 & 100,000 & 10,000 & 12,500 & 248,750 & 500 & 497.5 & 25.1 \\
\hline
\end{tabular}

Tables 5, shows that in 2009 Stock market, Investors that traded with First bank did not obtained any profit/dividends due to the Global economy meltdown that caused great loss on invested incomes. While Investors that traded SKYE bank experienced a low earnings growth.

Table 6: Stock Market Data from Data Bank Exchange Rate for SKYE Bank

\begin{tabular}{|l|l|l|l|l|l|l|l|}
\hline YEARS & $\begin{array}{l}\text { Volume } \\
\text { traded('000) }\end{array}$ & $\begin{array}{l}\text { Opening } \\
\text { Price(1000 } \\
\text { units) }\end{array}$ & $\begin{array}{l}\text { Closing Price } \\
\text { (1000 units) }\end{array}$ & $\begin{array}{l}\text { Net } \\
\text { Earnings(\#'000) }\end{array}$ & $\begin{array}{l}\text { Shares(1000 } \\
\text { units) }\end{array}$ & EPS(\#'000) & $\begin{array}{l}\text { P/E } \\
\text { RATIO(\#'000) }\end{array}$ \\
\hline 2007 & 30,000 & 2,500 & 3,000 & 14,850 & 300 & 49.5 & 60.6 \\
\hline 2008 & 40,500 & 4,300 & 4,500 & 8,000 & 500 & 16 & 281.2 \\
\hline 2009 & 52,000 & 4,000 & 3,700 & 51 & 1,000 & 0.0507 & -72978.3 \\
\hline 2010 & 65,000 & 5,000 & 5,500 & 32,100 & 800 & 40.1 & 137.1 \\
\hline 2011 & 70,000 & 5,000 & 6,000 & 69,500 & 500 & 139 & 43.2 \\
\hline
\end{tabular}


It is an important ratio that provides a basis for comparing the relative worth of two or more companies. P/E Ratio is also sometimes known as "price multiple" or "earnings multiple". In general, a high $\mathrm{P} / \mathrm{E}$ suggests that investors are expecting higher earnings growth in the future compared to companies with a lower P/E. However, the relationship trends of these stock parameters can be summarize and deduce with the graphical representation of tables 4, 5, and 6 .

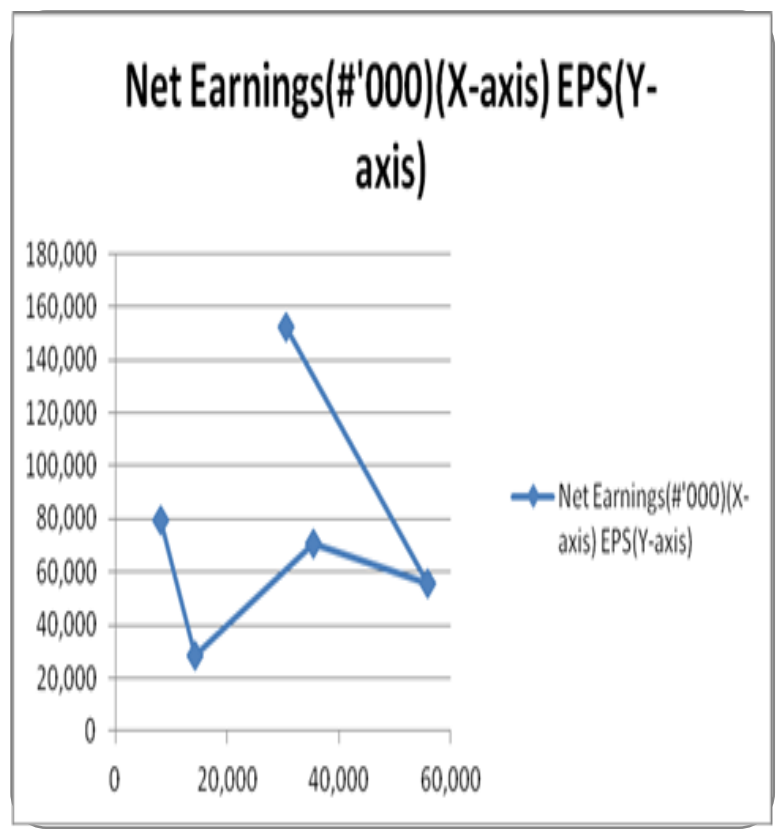

Figure 4: Company Net Earnings against Earning Per Share (EPS)

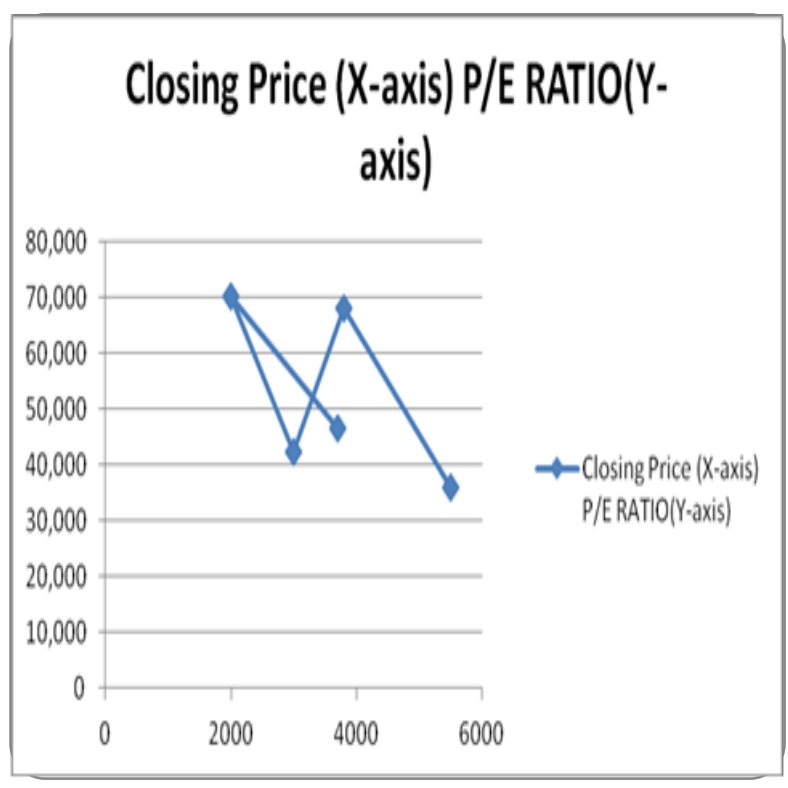

Figure 5: Current Market Price of Stock against P/E Ratio

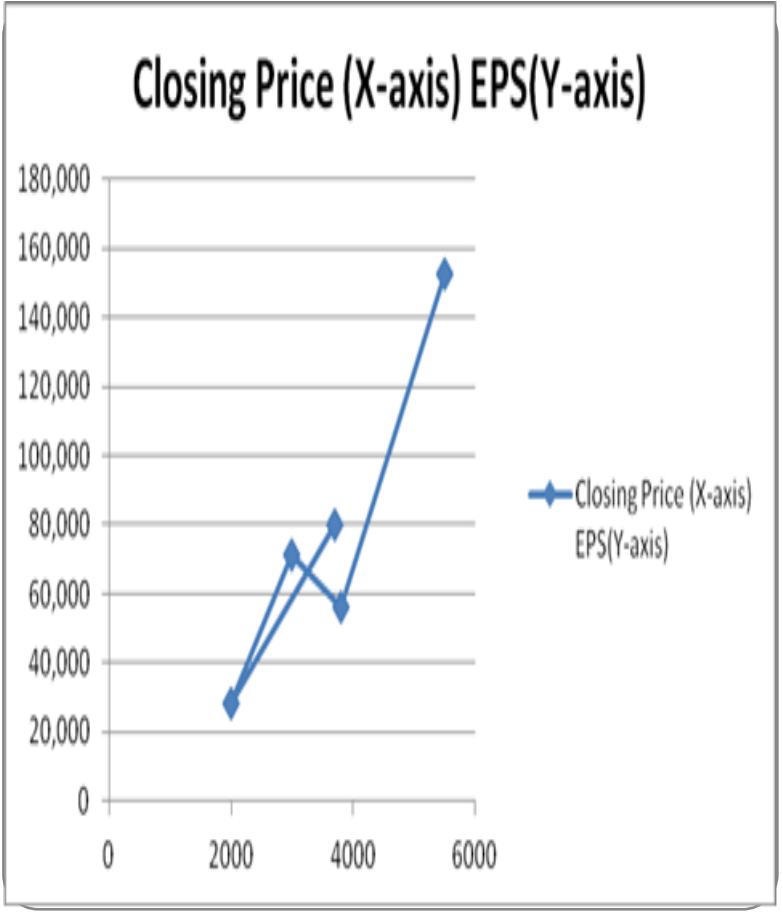

Figure 6: Current Market Price of Stock against Earning Per Share (EPS)

Figure 4 measures the company's profitability against each share sold. It shows that the company achieved high profit at an EPS of N30, 500.Figure 5 shows the fluctuation in Stock prices. At a high $\mathrm{P} / \mathrm{E}$ Ratio, the company's market price was low which also attracts investors. While on a low P/E Ratio, the company's price was high and investors tend to exercise caution when investing. Figure 6 shows that at a high market price, a huge profit was achieved on each share sold. This will boost investors' confidentiality of the company in the nearest future and also predict their stand in subsequent stock dealings.

\section{DISCUSSION}

The analysis was done in order to note the advantages of the system and to clarify how it could help in forestalling future occurrence of fluctuations. The system has lots of advantages over the existing system. Some of the facilities can be categorise as:

(1) Investor:The new system helps investor in predicting prices based on various situations and conditions, thereby helping them in making instantaneous investment decisions.

(2) Shareholder: The new system will expands the shareholder base of predicting the stock price and buy a stock before the price rises, or sell it before its value declines. It also increases support for shareholder protection.

(3) Company: The new system induces companies to issue more equity which will yield high profits and thereby leads to a broader stock market. It will also help in evaluating and forecasting the performance of the company.

(4) Government: This new system will regulate the effect of the Unknown Factors (Election Results, Rumours, and Political Effects etc.) on Stock Prices. 


\subsection{What Went Wrong?}

The main problemof fluctuations in stock market can be categorise as lack of Knowledge Management from the Government, Investors, Companies and Shareholders. From the results, it is agreed that the origin of the sub-main crises are due to a gathering of factors notably:

i. Low real interest rates in the US which was maintained for a long-time prior to the crises thereby encouraging accommodating monetary policy.

ii. Extreme confidence about the continued rise in housing prices and low volatility in the UShousing market. Between 1996 and 2005, US housing prices nationwide went up about 90 per cent. They went up 60 per cent between 2000 and 2005, and in the 30 year run-up to the crisis, rarely did housing prices fall.

iii. A shift in mortgage lending toward the less creditworthy, marginal borrowers, or subprime borrowers who do not qualify for prime mortgage. Also, in the sub-prime market, more than half of the loans were made by independent mortgage brokers who were not supervised at the federal level, unlike banks and thrift institutions.

iv. Incentive problems associated with the safety model for the mortgage loans intomortgage backed securities. There were also incentive problems for the self-regulating credit rating agencies, who were equally heavily involved in developing the structured product they rated.

v. High operating cost: Unarguably the cost of doing business in Nigeria is high. Inadequacy of basic Infrastructures like good roads, power supply, water supply, security of lives and property among others are lacking, leading to high cost of doing business

\subsection{Impact on the Nigerian Economy}

The fluctuation in market shares has led to led to the loss of confidence of banks and other lenders on shares as collateral for loan facilities. Shares which were before the crisis readily accepted by banks as collateral are now shunned by them. The crisis which manifested itself globally in the form of liquidity and credit crisis, de-leveraging and banks inability to improve capital adequacy, weak consumer demand, and fall in global output, affected Nigeria through both the financial and real (trade, remittances and aid) channels. The undiversified nature of the Nigerian economy and the high dependence on exports of crude oil as well as foreign capital inflows compounded the impact of the external shock arising from the crisis.

In specific terms, Nigeria experienced low demand for its oil export due to recession in the economies of her major trading partners.The global financial developments, especially the credit crisis caused a collapse of stock markets across the world, which have brought to the open the collective vulnerabilities of sovereign economies. Changes in currency prices (exchange rate) are central in transmitting localized economic developments to other geographical domains with regard to its function in trans-border trade and investment. In addition, The Stockbrokers are financially incapacitated and unable to settle their clients for securities sold. Many stock broking firms cannot discharge their obligation to their clients. Proceed of shares sold by these stockbrokers for their clients are greedily seized by the banks to which the stock broking firms owe through margin accounts.

\section{CONCLUSION}

This work studies the Nigerian stock market and analysis its data using neural networks. NN are efficient methods in the area of stock market predictions, but there is no "recipe" that matches certain methodologies with certain problems. Neural networks are most implemented in forecasting stock prices and returns, although stock modeling is very promising problem domain of its application. It has been observed that the most frequent methodology is the forward propagation algorithm though the importance of integration of neural networks with other artificial intelligence methods is emphasized to be of a better performance.

From the analysis, it can be concluded that the fluctuation rate has very serious implications on the Nigeria economy. Hence, for any serious development of the stock market there is need to stabilize the exchange rate movement. If exchange rate depreciation reduces stock market return, fluctuations can be averted if past knowledge is well studied and made active. Increase in government participation in the market will make the Nigeria stock market strong again

\section{REFERENCES}

[1] Nwude E. C. (2012), The Crash of The Nigerian Stock Market: What Went Wrong, The Consequences and The Panacea, Developing Country Studies, ISSN 2225-0565, 2, 9, 105- 117.

[2] Rai, P and Rai, k. (2011), Comparison of Stock Prediction Using Different Neural Network Types, International Journal of Advanced Engineering \& Application, January issue, 157-160.

[3] Afshari H. (2005). Structural measurement of forecasting stock price in Tehran stock exchange, measuring accounting and auditing. Manage. Fac. Tehran Univ., 32: 103-126.

[4] Owusu-Nantwi, Victor ${ }^{2}$ and John K. M. Kuwornu (2011). Analyzing the effect of macroeconomic variables on stock market returns: Evidence from Ghana, Journal of Economics and International Finance, 311, 605-615.

[5] Obiechina, M. E. (2010), Capital Flows and Financial Crises: Policy Issues and Challenges for Nigeria, Economic and Financial Review, 48(1), 93-112.

[6] Olaniyi, T. A. and Olabisi, O, Y. (2011), Causes and impacts of global financial crisis on the performance of Nigerian banks (a case study of selected banks), E3 Journal of Business Management and Economics Vol.2 (4). pp. 164-170.

[7] Ashamu, S. O. and Abiola, J. (2012), The Impact of Global Financial Crisis on Banking Sector in Nigeria, British Journal of Arts and Social Sciences ISSN: 20469578, 4,2, 251-257.

[8] Jenrola, O. A. and Daisi, O. R. (2012) The Implications of Global Financial Crisis on the Nigerian Capital Market Performance:An Empirical Investigation (2000-2008), European Journal of Humanities and Social Sciences, ISSN 2220-9425, 16,1, 803-819.

[9] Shar, V. A. (2007).Machine Learning Techniques for Stock Prediction, www.VatsahAShar. 
[10] Avramov D (2002). Stock Return Predictability and Model Uncertainty, Financial Economy, 64, 423-458.

[11] Gadanecz, B. (2007), "Recent initiatives by the Baselbased committees and groups", BIS Quarterly Review, September.

[12] Salehi M., Khodadadi V., and Abdolkhani, H. (2011). Forecasting stock price using artificial neural networks: A multi-layer perception model - Iranian evidence,Scientific Research and Essays, 6, 19, 40294038.

[13] Shorouq Fathi Eletter, Saad Ghaleb Yaseen and Ghaleb Awad Elrefae (2010). Neuro-Based Artificial Intelligence Model for Loan Decisions, American Journal of Economics and Business Administration 2, 1, 27-34.

[14] Mitchell David and Pavur Robert, (2002) .Using Modular Neural Networks for Business Decisions, Management Decision 40/1.
[15] Collins, E., Ghosh, S. and Svofield, C. (1998), An Application of a multiple Neural Network Learning System to Emulation of Mortgage Underwriting Judgements., Proceedings of the IEEE International Conference on Neural Networks, 2, 459-466.

16] Aas, K., Huseby, R. B. and Thune, M. (1999), 'Data mining: A survey', Report, NorwegianComputing Center. ISBN 82-539-0426-6.

[17] Dutta, S., and Shekhar, S. (1998), Bond Rating: A Nonconservative Application of Neural Networks., Proceedings of the IEEE International Conference on Neural networks, 2, 443-452.

[18] Moody, J., Saffell, M., 2001. Learning to Trade via Direct Reinforcement, IEEE Transactions on Neural Networks, 12, 4. 